\title{
Self-help-group (SHG): Toward Increasing Prosperity for Tobacco Farmers in Temanggung Regency, Indonesia
}

\author{
Achmad Sofiyudin, Azyani Zulfatindayu, Alvita Ega Mawarni, Nadya Audina \\ Department of Public Administration \\ Faculty of Social and Political Science, UNS \\ Surakarta, Indonesia \\ (sofiahmad02@gmail.com)
}

\begin{abstract}
The best of Indonesian tobacco produced in the district of Temanggung, Central Java. However, condition of tobacco farmers there turned out to be far from prosperous. Data from the official website YLKI (2008) mentioned that the wages of farmers and farmer workers on average only about Rp413.374 / month.

In the district of Temanggung existing Association of Indonesian Tobacco Farmers (APTI) that embodies the Temanggung tobacco farmers with a program of Independent Business Credit Tobacco Growers (KUMPT). KUMPT is a capital assistance program for develop of agribusiness in there. Unfortunately, the existence of APTI with KUMPT program is not be a solution to improve the welfare of farmers.

Self Help Group (SHG) can be an alternative solution for tobacco farmer community in the district of Temanggung. The mechanisms of SHG can be going with three steps, there are input, process, and output (the autonomous of tobacco farmers, tobacco farmers increased bargaining power and the capacity building of tobacco farmers). The first development type of SHG model form tobacco farmers is empowerment of tobacco farmers for the provision of access and information in terms of human resources management, conducting consultation and facilitating tobacco farmers. And the second is economic empowerment through the provision of capital support to Capital Tobacco Money Single (UMT2), agribusiness plan preparation, training and mentoring farm-preneurship in developing businesses agricultural activities. The final goal of tobacco farmers out of poverty and create prosperity for tobacco farmers.
\end{abstract}

Keywords-Tobacco farmer; Self-Help-Group (SHG); Micro Credit; Increasement prousperous

\section{INTRODUCTION}

Indonesia was the largest and best quality tobacco producer derived from Temanggung named Tobacco Srintil with nicotine $4-8 \%[1]$. However, based on Lembaga Demografi Fakultas Ekonomi Universitas Indonesia in collaboration with Tobacco Control Support Center (TSCS) research in 2008 showed that tobacco farmers prosperous not as good as perceived because the average of fee farmers and laborers was about Rp. 413.374/month [2].

Tobacco farmers poverty in Temanggung happened because the weakness position of farmers through establish tobacco selling price to broker. So far, the selling price of tobacco from the farmers to broker was still very low while the existence of APTI can't accommodate farmers right for bergaining position [3]. Monopsony market system in Temanggung is one of the reason tobacco farmers poverty [2]. Monopsony market system means many seller than buyers. Poverty tobacco farmers getting worse when they have no role for determination of price, quality, and amount of tobacco. Based on Nuryanti (2013) research, to fixing the problems, government (Agriculture Departement) and people who care about tobacco farmers prosperous form organization named Tobacco Farmers Indonesia Association or APTI [3].

Responding the problems of capital for tobacco farmers, APTI has issued credit policy named Kredit Usaha Mandiri Petani Tembakau (KUMPT) [3]. On this program, APTI colaborate with Mandiri Bank as a partner. However in the implementation of the program is not going well because tobacco farmers must pay the $1,5 \%$ interest loan for every loan[3]. This program is not a solution to develop tobacco business. So, advocacy function for tobacco farmers is not effective for improving prosperous of tobacco farmers.

Sanjay Kanti Das (2012), in similar case explained that Self Help Group (SHG) play important role in case of decreasing poverty in rural areas India [4]. SHG was helped farmers during the problem of poverty and lack of capital access and technology (Kanti Das, 2012) [4]. This article was help SHG's tobacco farmers in Indonesia that rare to do by other researcher. In addition, this article will disscuss how the role of SHG as an alternative solutions to decreasing the tobacco farmers poverty in Temanggung, Indonesia.

\section{LITERATURE REVIEW}

Gandhi mathi and Sugasini (2014) explained that the farmers are disadvantageously placed with respect to their access to technology, capital, credit and other institutional support. So the Self Help Group (SHG) was formed with the aim to improving the standard living of farmers [5]. The other researchers Sanjay Kanti Das (2012) mentioned that Self-Help Groups (SHGs) are playing a major role in removing poverty in the rural India today [4]. SHG has been applied to farmers in India who had been experiencing a variety of problems such as 
poverty and lack of access to capital resources and technology [4].

In connection with capital problem for farmers, Vikas Batra (2012) in the study of SHG in Haryana explained that the members make regular savings and use the pooled savings to give interest-bearing loans to their members [6]. The process helps them imbibe the essentials of financial intermediation including prioritization of needs, setting self-determined terms for repayment and keeping books and records. It builds financial discipline and credit-history that encourages banks to lend them in certain multiples of their own savings and without any demand for collateral security [6].

Kalaiselvi and Muruganandam (2008) in a case study in India showed that micro credit programme plays an important role in the potential for the alleviation of poverty. Experience shows that micro credit can help the poor to increase income and build viable businesses [7]. Government could take some actions like improving the general education level, initiating marketing awareness programmes to increase the effective utilization of micro credit, and providing more financial education (Kalaiselvi dan Muruganandam, 2008) [7].

Gandhimathi and Sugasini (2014) in the study formulated hypotheses that marginal and small farmers were the beneficiaries of self help group. The farmer members of self help group were able to allocate the farm inputs efficiently. Additional amount of credit could increase the farm production of marginal and small farmers [5].

SHG in India tend to have a satisfactory performance in implementing micro-finance program (Rashid and Imtiyaz, 2013) [8]. Porkodi and Aravazhi (2013) suggested the government should focus on creating an environment by providing public infrastructure to reduces transaction cost in remote areas like connectivity, encouraging competition among financial providers, focusing on rules based regulation to minimize political risk, wide publicity and strictly implementing the concept of Financial Literacy and Credit Counseling to educate the public in proper utilization of financial services offered by the service providers [9]. Financial inclusion will be real and successful only when the small and marginal farmers and landless labourers have unhindered access to the financial services like savings, credit, micro insurance and remittance facilities [7].

\section{SOLUTION}

Based on research that we mentioned before, SHG Tobacco Farm can be an alternative solution. SHG Tobacco Farm is a community who made from awareness farmers with their same problem. They have awareness to change their fate for the better life. With this community they coordinate and makes a strength and wide network between tobacco farmers. In other case SHG Tobacco Farm become an accessibility for tobacco farmers in order to have a bargaining position and also to create innovations in agribusiness development.

This SHG Tobacco Farm has a model who consist inputprocess-output stage. Input is capital investment as a social capital investment from tobacco farmer at Temanggung regency, the process is community development model and development save tobacco farm activity as division from SHG Tobacco farm. The form model of development community stage is to develop awareness of the tobacco farmer and stage for develop community. And than, the first form of save tobacco farm develop model is to inventive the tobacco farm, it's mean the tobacco farmers is gived acess and information in order to manage human resources and do the consultancy and facility the tobacco farmer. The second is to inventive economy by giving help capital investment in form Single Modal Tobacco Money (SMTM), create agribusinessplan, training and counseling farm-preneurship program in order to develop agriculture. Finally, these effort can make output, there are the tobacco farmer can be own master farmer, and they have a bargaining position and also get education acces. Furthere more, the golden gold is the tobacco farmers are not trap in proverty and their life more be prosperous than before.

\section{REFERENCES}

[1] Andri, Kuntoro Boga, Juni 2012, Analisa Manajemen Rantai Pasok Agribisnis Tembakau Selopuro Blitar Bagi Kesejahteraan Petani Lokal, Seminar Nasional: Kedaulatan Pangan dan Energi Fakultas Pertanian Universitas Trunojoyo Madura. http://pertanian.trunojoyo.ac.id

[2] Survey Yayasan Lembaga Konsumen Indonesia (YLKI) Tahun 2008.

[3] Nuryanti, 2013, Strategi Komunikasi Asosiasi Petani Tembakau Indonesia Dalam Pemberdayaan Petani Tembakau Di Kabupaten Temanggung,11/324466/PMU/07196. http://etd.repository.ugm.ac.id/

[4] Das. Sanjay Kanti,2012, Ground Realities of Self Help Group - Bank Linkage Programme: an Empirical Analysis, International Journal of Research in Social Sciences, Vol. 2(2), pp 464-479, http://www.ijmra.us

[5] Mathidan. Gandhi, Sugasini,2014, Impact of self help group financing on agricultural production - An empirical analysis in Salem District of Tamilnadu, Journal of Agricultural Economics and Development, Vol.3(6),pp.084-093, http://academeresearchjournals.org/journal/jaed

[6] Batra, Vikas. 2012. IJMRS's International Journal of Management Sciences, Vol. 01, Issue 0. www.ijmrs.com

[7] Kalaiselvi, Muruganandam,2008, A Study of a Micro Credit Programme run by Self-Help Groups in Tamilnadu State, India, Journal of Finance and Management in Public Services, Volume 9(2), pp 25-38, http://eprints.cscsarchive.org:8080/jspui/hand

[8] [Wani. Rashid Rasheed, Imtiyaz-ul-Haq,2013, Performance of Self Help Groups under Micro-finance Programme in Kashmir Valley- A Case Study of Block Kulgam, International Research Journal of Agriculture and Rural Development, Vol. 2(1), pp2-14 http://irjard.nonolympictimes.org/Articles/IRJARD2.pdf

[9] S. Porkodi, D Aravazhi,2013, Role Of Micro Finance and Self Help Groups in Financial Inclusion, International Journal of Marketing, Financial Services \& Management Research, Vol. 2(3), pp 137-149 http://indianresearchjournals.com/pdf/IJMFSMR/2013/March/13.pdf 